\title{
Comentário dos Editores de OP, vol. X, nº 1, maio de 2004
}

Ao publicar o terceiro número em colaboração com o CESOP e a Universidade de Campinas, a ABCP teve alguns objetivos: o principal é definir-se como uma organização profissional que, mesmo representando os cientistas políticos do país, se preocupa com o desenvolvimento institucional da Ciência Política - revistas, centros de pesquisa, programas de graduação e de pós-graduação, departamentos, universidades. Procuramos apoiar e, se solicitados, melhorar as iniciativas e não competir com elas. Estamos tentando criar a Revista Brasileira de Ciência Política, apoiar a criação de uma revista interdisciplinar, dedicada à pesquisa empírica nas ciências humanas, Empiria, o que não nos impede de apoiar as revistas já existentes, particularmente aquelas, como OPINIÃO PÚBLICA, com excelente padrão de qualidade. Os pesquisadores brasileiros reclamam da insuficiência do número de revistas especializadas e não do seu excesso.

Objetivamos, também, diversificar a informação que chega ao país e é disseminada pelos formadores de opinião - pessoas que ensinam e publicam na área. Nosso diagnóstico indica que conhecemos bem a Filosofia e a História políticas produzidas na Europa, mas conhecemos pouco as excelentes pesquisas realizadas no continente europeu; conhecemos algo das inúmeras pesquisas realizadas nos Estados Unidos e demais países anglo-saxônicos, mas pouco da teoria política, usualmente focalizada e bem delimitada, produzida no mesmo espaço; finalmente, nosso conhecimento sobre os países do Terceiro Mundo é parco, inclusive sobre a América Latina. Daí a inclusão de artigos baseados em pesquisas de latinoamericanos e europeus sobre a América Latina. Nossa colaboração foi orientada para diminuir essas deficiências. OPINIÃO PÚBLICA é, simplesmente, uma excelente revista cujas orientações se afinam com as nossas, parte fundamental do tripé colaborativo, cuja terceira perna é a revista América Latina Hoy, publicada na Universidade de Salamanca.

Cabe ao leitor avaliar a qualidade e a utilidade desses números em colaboração.

\section{Gláucio Ary Dillon Soares, Presidente} Associação Brasileira de Ciência Política

Essa terceira parceria de OPINIÃO PÚBLICA com a Associação Brasileira de Ciência Política marca um período de consolidação para a Revista.

A experiência de trabalho conjunto possibilitou que $O P$ potencializasse suas metas de fortalecer a disciplina, ampliar o conhecimento e intercâmbio entre pesquisadores e seus trabalhos, consolidar um espaço de reflexão sobre as realidades brasileira e latino-americana.

A relação com a revista America Latina Hoy foi parte dessa iniciativa, e os exemplares OP vol. VIII $n^{\circ} 2$, de 2002; OP vol. IX n¹, de 2003 e agora $O P$ vol. $X n^{\circ} 1$ traduzem essa intervenção.

Nossa aproximação com a ABCP e o importante estímulo de seu presidente conferiram-nos maior reconhecimento como veículo científico especializado. Com mais este número de $O P-A B C P$, ganhamos todos, comunidade científica e leitores em geral.

\section{Rachel Meneguello, Editora Opinião Pública/CESOP}

